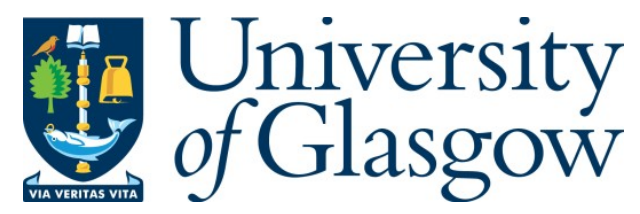

Yang, S., Isa, S. M., Ramayah, T., Blanes, R. and Kiumarsi, S. (2020) The effects of destination brand personality on Chinese tourists' revisit intention to Glasgow: an examination across gender. Journal of International Consumer Marketing, 32(5), pp. 435-452.

(doi: 10.1080/08961530.2020.1717400)

This is the Author Accepted Manuscript.

There may be differences between this version and the published version. You are advised to consult the publisher's version if you wish to cite from it.

https://eprints.gla.ac.uk/210166/

Deposited on: 19 February 2020

Enlighten - Research publications by members of the University of Glasgow http://eprints.gla.ac.uk 


\title{
The Effects of Destination Brand Personality on Chinese Tourists' Revisit Intention to Glasgow: An Examination across Gender
}

\author{
Shaohua Yang ${ }^{1}$ Salmi Mohd Isa ${ }^{2}$ T. Ramayah ${ }^{3}$ Ramona Blanes ${ }^{4}$ Shaian Kiumarsi ${ }^{5}$ \\ ${ }^{1,2,5}$ Graduate School of Business, Universiti Sains Malaysia, 11800 Penang, Malaysia \\ Email: samuelyang0713@hotmail.com; salmi.mohd.isa@usm.my; shaian@usm.my \\ ${ }^{1,4}$ Adam Smith Business School, University of Glasgow, G12 8QQ, United Kingdom \\ Email: shaohuayang@student.usm.my; Ramona.Blanes@glasgow.ac.uk \\ ${ }^{3}$ School of Management, Universiti Sains Malaysia, 11800 Penang, Malaysia \\ Email: ramayah@usm.my
}

\begin{abstract}
The aim of this research is to examine the mediating effects of self-congruity between destination brand personality, to revisit intention and heed the moderating effects of gender between self-congruity. Therefore, data were collected through a survey from 226 Chinese outbound tourists in Glasgow city, United Kingdom and was analysed to provide evidence. Based on the results, the analysis of partial least squares structural equation modelling (PLSSEM) using the Smart PLS 3.0 program indicated that self-congruity was mediated partially through destination brand personality and revisit intention. In tourism destination, Aaker five dimension of brand personality model was particularly adapted into practice. However, the model failed to perform an actual self-congruity to mediate all five dimensions (i.e. sincerity, excitement, competence, excitement, sophistication and ruggedness) of destination brand personality and revisit intention. The results revealed that the ideal self-congruity is a mediating effect between destination brand personality (i.e. sincerity and excitement) and revisit intention. Moreover, this study also reported that the moderating role of gender has no effects on selfcongruity and revisit intention. No difference was observed between female and male Chinese tourists who rely more on destination brand personality over self-congruity when the impact of symbolic destination brand benefits on their intention to revisit Glasgow was considered. Findings further offer specific implications for both theoretical insight and marketing practice in context of tourism destinations in Glasgow.
\end{abstract}

Keywords: Destination brand personality, self-congruity, revisit intention, Chinese tourists 


\section{Introduction}

Destination branding emerges as one of the crucial tools used in the development of competitive advantage of destination marketing organizations (DMOs). The competitive nature in today's tourism industry encourages destinations to develop their own brand and establish effective promotion to tourists (Huang, Zhang, and Hu 2017). In addition to promoting unique attributes of destination, including beautiful scenery, beaches, heritage, and friendly local citizens, strategies are also implemented to attract tourists. Therefore, the construct of destination brand personality has remained as a widespread research agenda in tourism to illustrate individual perceptions' destination (e.g. d'Astous and Boujbel; Boksberger, Dolnicar, Laesser, and Randle 2011; Ekinci and Hosany 2006; Hosany, Ekinci and Uysal 2006; Liu, Huang, Hallak, and Liang 2016; Matzler, Strobl, Stokburger-Sauer, Bobovnicky, and Bauer 2016; Usakli and Baloglu 2011; Yang, Isa and Ramayah, 2019). Based on the self-congruity theory, consumers prefer a brand that they perceive as reflective of their personalities (Landon 1974; Malhotra 1988; Sirgy 1982). Brand-self congruity, such as the match of a brand's image for an individual's self-concept (Sirgy and Su 2000), strongly affects brand-success variables, including consumer-brand identification (Stokburger-Sauer, Ratneshwar, and Sen 2012) and consumer's loyalty (Das 2014).

Tourism literature acknowledged the model of the relationship between destination brand personality, self-congruity, and tourist behavioural loyalty (e.g. revisit intention). To illustrate, several studies confirmed that destination brand personality had a direct influence on tourists' revisit intention (Apostolopoulou and Papadimitriou 2015; Chen and Phou 2013; Eisend and Stokburger-Sauer 2013a; Uşakl and Baloglu 2011). It was highlighted in previous literature that positive influence branding was obtained through a distinctive destination brand, as it contributed to differentiation of the brand (Uşakl and Baloglu 2011). Meanwhile, it was argued in other studies that the role of self-congruity fully mediated the relationship between destination brand personality and revisit intention (Uşakl and Baloglu 2011; Huang, Zhang, and Hu 2017; Su and Reynolds 2017). Ultimately, several scholars directly investigated the impacts of self-congruity on attitudinal and tourists' behavior towards brand success (Stokburger-Sauer et al. 2012). However, the information on the mediator of self-congruity between destination brand personality and revisit intention was still unclear especially for a particular city (Glasgow). Adopting the Aaker (1997) model of brand personality, the dimensions of brand personality can be used to describe different categories of products as well as customer backgrounds. To gain a better understanding of these variables in tourism settings, 
this study attempted to investigate individuals' perceptions of destination brand personality and tourists revisit intention in the context of Glasgow city. In line with Usakli and Baloglu (2011), it was suggested that these relationships are mediated through self-congruity, which is referred to as the tourists' perception of the similarity between their own personality and the Glasgow brand personality. In recent years, China has become one of the fastest increasing outbound tourism nations, reflected in a $300 \%$ rise in visitor numbers to Scotland. Also, most Chinese tourists visiting Scotland have a plan to revisit (Terry 2019). However, due to the strong destination brand of Edinburgh, Chinese tourists prefer to visit Edinburgh compared to Glasgow. Edinburgh is now the second most-visited city in the UK by Chinese tourists after London (Wang 2019). Other national tourists also noted that Glasgow had a vibrancy that is underrated. (Edinburgh News 2016). To build a competitive advantage in Chinese tourists' market for DMOs in Glasgow city, it is important to examine the tourists' behavioral toward revisit Glasgow through a theoretical model.

To attempt to integrate the theoretical model of destination brand personality, self-congruity, and revisit intention, another concept was identified. Demographic factors, such as gender, are possibly the crucial predictors of tourists' behavioural intention. According to Li et al. (1999), gender was studied as the factors influencing purchase behaviour (Li et al. 1999). With respect to gender factors, it was found in the analysis of customers on the gender factor that the behaviours of male and female were highly varied (Kolyesnikova et al. 2009). Essentially, their behaviours only had significant difference (Kolyesnikova et al. 2009). However, this difference became significant when shopping was concerned (e.g. Bakewell and Mitchell 2004; Dholakia 1999).

It was also agreed that individuals' perceptions of brand benefits differed from gender to gender due to the difference between them in terms of brand personality dimensions (Grohmann 2009). In the context of tourism, male and female tourists also produced different results in terms of travel activity preferences (Kim and Jogaratham 2003), with females reporting a higher tendency to travel for leisure purposes compared to males (Collins and Tisdell 2002). It was also shown in the works of tourism literature that gender influenced revisit intention (Abubakar, Ilkan, Al-Tal, and Eluwole 2017; Dedeoğlu, Balıkçığlu, and Küçükergin 2016; Han et al. 2009). Therefore, due to the difference between the genders in terms of destination brand personality and tourists' behaviour, it was assumed that the impact of destination brand personality and self-congruity on revisit intention would be varied as well. However, there was 
an insufficient study conducted on this matter. For this reason, it is important to investigate the moderating effects of gender on the relationship between self-congruity and revisit intention, which would assist in DMOs in Glasgow in formulating and implementing Chinese tourists' gender-related marketing strategies, including segmentation, position, and promotion among others.

Based on the data obtained from 226 Chinese outbound tourists in Glasgow city of the UK and their perceptions of Glasgow as a tourism destination, an empirical test was conducted on the mediator of self-congruity between destination brand personality and revisit intention. This test was also performed on the moderating role of gender on the relationship between self-congruity and revisit intention. Notably, city brand personality perception, self-congruity, and the Chinese outbound tourists' genders, which played the most important roles in gender factors and self-congruity (Lam et al. 2012), were investigated.

The research objective of this study was to examine the self-congruity as a mediating effect between the multi-dimensions of destination brand personality and revisit intention among Chinese tourists in Glasgow. Moreover, this study also examined the moderating effects of gender on the relationship between self-congruity and revisit intention among Chinese tourists in Glasgow. In fulfilling this study's objectives, several contributions have been offered through this empirical paper. First, this study has contributed to the understanding of a conceptual model by elaborating on the interrelationships between multi-dimensions destination brand, personality, self-congruity, gender, and revisit intention. Second, this study has also contributed to an improved understanding of the mediating role of self-congruity in the relationship between multi-destinations of destination brand personality and revisit intention. Third, this study has contributed to the body of tourism marketing literature by exploring the moderators of gender in terms of self-congruity and revisit intention.

\section{Theoretical background and hypothesis development}

According to the behavioural theory in consumer studies, purchasing decision is often based on an individual's self-concept (Sirgy 1982). Self-concept is defined as the totality of an individual's perceptions in relation to social context, be it intellectual or affective (Onkvisit and Shaw 1987). It is a multi-faceted entity, which expresses an individual's regarding themselves and the ideal self that they aim to be in the future (Sirgy 1982). In Hayakawa's 
(1963) perspective, all human activities involve the protection, maintenance, and enhancement of their self-concept or symbolic self.

It was stated by researchers in the psychology discipline that self-concept usually emphasises the particular behavioural patterns (Onkvisit and Shaw 1987), leading to the implications of consumers, which could influence their behavioural intention to products or services. These products would protect or reinforce their self-concept (Grubb and Grathwohl 1967). In other words, individuals do not only instil an image of themselves, but they also instil an image of products or brands, suppliers, and services (Litwin and Kar 2004). The theory of self-concept has revealed that consumers generally have favourable attitudes towards products and brands, which are perceived to be consistent with their self-concept. However, they harbour relatively less favourable attitudes toward products and brands which are perceived to be incongruent with their self-concept (Graeff 1996).

\section{Self-congruity}

Self-congruity is a natural extension of the self-concept theory (Usakli and Baloglu 2011). This theory is multidimensional and it consists of an actual self-congruity, ideal self-congruity, social self-congruity, and ideal social self-congruity (Sirgy 1982). Sirgy (1982) elaborated that self-congruity theory reinforces the idea that consumer perceptions, or leanings, are achieved through a match between the product idea/image and the consumer's self-perception in favour of certain items. Furthermore, Litwin and Kar (2004) argue that higher congruency between product/image and consumers' self-concept would enhance one's intention to purchase the product/service.

A detailed discussion of this theory has been conducted for almost a half-century (e.g. Birdwell 1968; Dolich 1969; Grubb and Stern 1971; Hughes and Guerrero 1971; Sirgy 1982). Over the last 40 years, this theory has been widely applied in marketing and consumer literature (Aguirre-Rodriguez, Bosnjiak, and Sirgy 2012; Claiborne and Sirgy 1990; Johar and Sirgy 1991; Sirgy 1982 1985a 1985b; Sirgy, Johar, Samli and Claiborne 1991; Sirgy and Su 2000; Sirgy, Lee, and Yu 2017). It was concluded from these studies that self-congruity influenced consumers' behaviour in terms of their product or service preferences and the willingness to purchase or repurchase. 
Furthermore, the majority of the aforementioned studies over-generalised the theoretical model which was linked with a product brand, self-congruity, and behavioural intention. In fact, selfcongruity functions as the mediator between product brand and behavioural intention. An assertion was developed from tourism studies conducted by various scholars on the self-image congruence construct with an aim to explain on tourists' behaviour (Litvin and Goh 2002; Sirgy and Su 2000; Todd 2001). However, most tourism studies also operationalised self-congruity in terms of two dimensions, namely actual self-congruity and the idea self-congruity. This selection was due to the perception that social self-measures were highly-correlated with these two dimensions (Beerli et al. 2007; Chon 1992; Ekinci and Riley 2003). Moreover, it was found in an earlier study by Sirgy (1982) that actual self-congruity and ideal self-congruity were the multiple dimensions of self-congruity which received the most theoretical considerations and empirical supports. Due to the moderator variable involved in Sirgy's study, two dimensions, namely the actual and ideal self-congruity, might significantly contribute to a robust validity of the measurement model.

\section{Conceptualisation of gender}

The differentiation between female and male is a crucial component in this study. Therefore, in developing a hypothesis on the moderating role of gender, it is crucial to clearly conceptualise this variable in current study. Two streams of studies were found to be mainly focused on gender differences in terms of biological sex (e.g. Chang 2006; Worth et al. 1992) and gender identity (e.g. Gould and Weil 1991; Kahle and Homer 1985). Based on the first stream of study, gender was defined as biological sex, referring to males and females (Kolyesnikova et al. 2009), while another stream signified gender as 'gender identity' (Gould and Weil 1991). This definition of psychological sex indicated two-dimensional phenomena, where one dimension consisted of the feminine personality traits, while another dimension comprised masculine traits (Palan 2001). It was indicated in several studies that gender identity could be the determinants of consumers' behaviour in certain aspects, such as its occasional effects on consumers' attitudes (e.g. Worth et al. 1992). However, other scholars questioned the importance of gender identity in studies on consumers' attitudes (Kolyesnikova et al. 2009) due to insufficient important findings of gender identity in these studies (Palan 2001). Based on the comparison between the influences of biological sex and gender identity, it was highlighted that biological sex held a more significant role in determining consumer-brand relationship compared to gender identity (Allison et al. 1980; Kahle and Homer 1985; Gould and Weil 1991). Palan (2001) also suggested that biological sex was a more practical 
segmentation variable. Based on the aforementioned previous findings, gender would be identified as biological sex (e.g. males and females) in this study.

\section{Proposition Development}

\section{Destination brand personality, self-congruity, and revisit intention}

Due to the acknowledgement that consumers often favoured brands related to their personalities and chose a certain brand to express themselves, Aaker (1997, p. 347) developed the conceptualisation of brand personality and defined it as a set of human characteristics related to a brand. Furthermore, Aaker (1997) developed five theoretical dimensions of brand personality scale, which were branched into 42 personality traits, such as sincerity, excitement, competence, sophistication, and ruggedness. Extensive studies were conducted on the use of these traits describe brands (Eisend and Stokburger-Sauer 2013b), where scales of measurement were developed to assess brands in relation to the traits. Moreover, the dimensions of brand personality were applied in various settings across different cultures to measure consumers' symbolic consumption and its impact on their behaviours (Ekinci and Hosany 2006).

Extensive studies had been performed on this matter in various contexts, such as product, service, and destination brands, to determine consumer behavioural intention. As a result, brand personally was found to be cross-culturally generalisable (e.g., Aaker et al. 2001; d'Astous and Boujbel 2007; Geuens et al. 2009), and it also involved the concepts of country, service, and, most recently, destination in the marketing context (d'Astous and Lévesque 2003; Ekinci and Hosany 2006; Lee, Back, and Kim 2009; Siguaw, Mattila, and Austin 1999). Naturally, it should be understood that general findings were often developed from these studies, including different outcomes in various contexts as different dimensions could be used to describe different categories of products, brands, and consumer demographic backgrounds. In this case, according to consumers' perspectives, the establishment of unique brand personality traits was an effective approach of distinguishing a brand from its competitors (Siguaw, Mattila, and Austin 1999).

Based on the works of tourism literature, with the adoption of Aaker's (1997) terminology of brand personality, it was suggested that the concept of brand personality could be extended to tourist destinations. Ekinci and Hosany (2006) conceptualised destination brand personality as a set of human characteristics related to destinations. It was found that tourists ascribe their 
personalities to destinations based on three salient dimensions, namely sincerity, excitement, and conviviality. As a construct, destination brand personality is, in fact, still a research subject which has been gaining interests research for years (Ekinci, Sirakaya-Türk, and Baloglu 2007; Kılıç and Sop 2012; Matzler et al. 2016; Pan et al. 2017; Usakli and Baloglu 2011). This could be seen from several studies which used different dimensions of destination brand personality on tourists' intentions to visit various tourist destinations (Chen and Phou 2013; De Moya and Jain 2013; Papadimitriou, Apostolopoulou, and Kaplanidou 2015).

Other studies provided empirical evidence to support the notion that tourists ascribe their personality traits to destinations (Murphy, Benckendorff, and Moscardo 2007; Usakli and Baloglu 2011). Specific, Murphy, Moscardo, and Benckendorff (2007) indicated in their study that tourists ascribed different personality traits to different tourist destinations. Furthermore, tourists perceived the different destination brand personality could be developed based on their demographic characteristics. For instance, Hosany, Ekinci and Uysal (2006) found that the personality characteristics of the UK based on tourists' perception were sincerity, excitement and vibrancy, and conviviality. Meanwhile, Muprhy, Moscardo and Benckendorff (2007) found that sincerity, excitement, and sophistication where the characteristics in relation to North Queensland of Australia. Two studies were conducted in other tourist destinations including South Korea and Taiwan. As a result, the characteristics of brand personality for these countries with all five dimensions were sincerity, excitement, sophistication, competence, and ruggedness (Kim and Lehto 2013; Liu, Lin, and Wang 2012). Xie and Lee (2013) identified that the destination brand personalities in China with the five dimensions were competency, excitement, sophistication, and ruggedness. On the other hand, Papadimitriou, Apostolopoulou, and Kaplanidou (2015) demonstrated that the brand personality of medium-sized Greek cities consisted of excitement and sincerity. Despite the numerous findings regarding destination brand personality in general, particularly at the country, national, or large geographical area levels, limited evidence was found on city region, such as Glasgow. Notably, various perceptions might be present among Chinese tourists in Glasgow regarding the characteristics of this city's brand personality.

To gain an improved understanding of tourists' perception of destination brand personality, most studies had incorporated self-congruity to investigate the relationship between destination brand personality and tourists visiting behaviour (Huang, Zhang, and $\mathrm{Hu}$ 2017). On a similar note, Usakli and Baloglu (2011) investigated the brand personality of Las Vegas based on 
tourists' perception. It was concluded that tourists definitely ascribed their personality traits to touristic destinations. Therefore, it was indicated that destination personality and self-congruity was a crucial determinant of revisit intention. It could also be seen that destination brand personality directly influenced tourist revisiting intention (e.g. Chen and Phou 2013; Chua, Kim, Lee, and Han 2019; De Moya and Jain 2013; Papadimitriou, Apostolopoulou, and Kaplanidou 2015; Usakli and Baloglu 2011).

Despite the criticism that tourists revisiting destination depends on the congruity of destination personality with consumer's self-concept (Sirgy 1982). According to the aforementioned description of the self-congruity theory in the theoretical background section, it is presumed in this theory that the intention of consumers' selection of products or brands was based on the brands' correspondence to their self-concept (Sirgy 1982). Furthermore, the self-congruity model was viewed based on theoretical assumptions with an aim to examine the mediator impact of self-congruity on the relationship between brand personality and consumer behaviour. It could be said that higher congruence between brand personality and the consumer's own personality would increase the tendency of consumers to choose the brand. Most scholars of tourism studies operationalised self-congruity based on the first two dimensions such as actual self-congruity and idea self-congruity, to determine behavioural intention (Beerli et al. 2007; Chon 1992; Ekinci and Riley 2003). It was indicated in several conceptual papers and empirical papers that actual self-congruity and ideal self-congruity played a role as a mediator between destination personality and revisit intention (Huang, Zhang, and Hu 2017; Khazaei Pool, Khodadadi and Asadi 2018; Usakli and Baloglu 2011; Yang, Isa, Ramayah, and Blanes 2019).

In term of multidimensions of destination brand personality, Usakli and Baloglu (2011) found that self-congruity (actual and ideal self-congruity) played a role as a mediator between the destinations of destination brand personality (i.e. sincerity, competence and competence ) and revisit intention. Liu, Lin and Wang (2012) confirmed the mediating effect of actual selfcongruity and ideal self-congruity between five dimensions (sincerity, excitement, competence, sophistication and ruggedness) and destination loyalty. In recent study, Rutelione, Hopenienè and Žalimiene (2018) identified that the five dimensions of destination brand personality (i.e. sincerity, excitement, competence, sophistication and ruggedness ) and self-congruity (actual and ideal self-congruity are positively related to revisit intention. The authors, however, did not propose the mediator role of actual and ideal self-congruity between five dimensions of destination brand personality and revisit intention (Rutelione, Hopenienė, and Žalimienė 2018). 
Therefore, based on the above theoretical assumptions and empirical findings, the following hypotheses are proposed:

Hypothesis 1: Actual self-congruity mediates the relationship between destination personality with sincerity and tourist revisiting intention.

Hypothesis 2: Actual self-congruity mediates the relationship between destination brand personality with excitement and tourist revisiting intention.

Hypothesis 3: Actual self-congruity mediates the relationship between destination brand personality with competence and tourist revisiting intention.

Hypothesis 4: Actual self-congruity mediates the relationship between destination brand personality with sophistication and tourist revisiting intention.

Hypothesis 5: Actual self-congruity mediates the relationship between destination brand personality with ruggedness and tourist revisiting intention.

Hypothesis 6: Ideal self-congruity mediates the relationship between destination brand personality with sincerity and tourist revisiting intention.

Hypothesis 7: Ideal self-congruity mediates the relationship between destination brand personality with excitement and tourist revisiting intention.

Hypothesis 8: Ideal self-congruity mediates the relationship between destination brand personality with competence and tourist revisiting intention.

Hypothesis 9: Ideal self-congruity mediates the relationship between destination brand personality with sophistication and tourist revisiting intention.

Hypothesis 10: Ideal self-congruity mediates the relationship between destination brand personality with ruggedness and tourist revisiting intention.

\section{The moderating role of gender}

Gender is a distinct segmentation variable which could be efficiently observed. However, it may consist of various subculture groups. As it is closely associated with consumptions, the impacts of gender on consumers' behaviour have been demonstrated in various studies. To illustrate, various studies investigated several aspects of different genders, including the processes underlying males' and females' judgment (Dube and Morgan 1996), gender strategies relating to information processing (Darley and Smith 1995), gift-giving (Laroche et al. 2000) and decision-making upon purchase (Mitchell and Walsh 2004). Early works of literature (Dolich 1969) indicated that gender is the main component of consumers' self- 
congruity. It was also stated that the need to express femininity and masculinity is possibly developed through brand choice. Furthermore, males and females are distinguished in terms of their shopping behaviours (Dholakia 1999). Specifically, males definitely held opposed values regarding "effective" shopping compared to females (Bakewell and Mitchell 2003, 2004, 2006). Due to their priority over time, males often shopped quickly, while females enjoy spent plenty of time and energy on shopping due to their interests in it. Moreover, males had less involvement in shopping compared to women (Dholakia 1999).

In the field of travel, female and male tourists displayed different preferences in travel activity and revisiting intention (Abubakar, Ilkan, Al-Tal, and Eluwole 2017; Akinci and Aksoy 2019; Dedeoğlu, Balıkçıoğlu, and Küçükergin 2016; Funk, Toohey, and Bruun 2007; Kim and Jogaratham 2003; Kim, Malek, Kim, and Kim 2017). To illustrate, females showed a higher tendency to travel for leisure compared to males (Collins and Tisdell 2002). Overall, it was demonstrated from these studies' findings that males and females were different in terms of shopping style, travelling style, and behaviour, which possibly moderated the influence of selfcongruity and revisiting intention to Glasgow among Chinese tourists. Therefore, the following hypotheses were developed:

Hypothesis 11: Gender moderates the relationship between actual self-congruity and tourist revisiting intention.

Hypothesis 12: Gender moderates the relationship between actual self-congruity and tourist revisiting intention.

According to the above hypotheses, the theoretical framework of this study is as follows (refer to Fig. 1) 


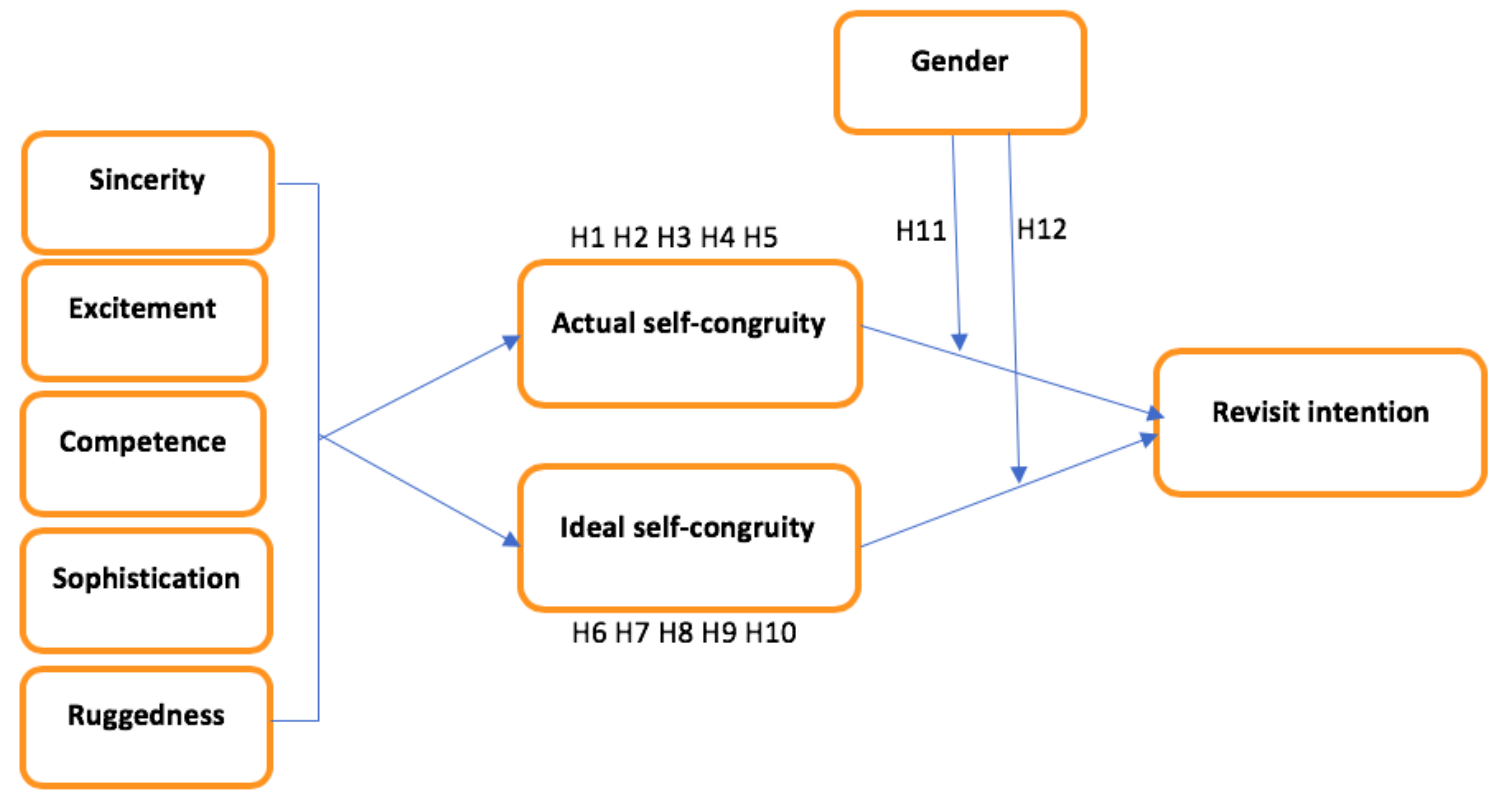

Figure 1: Theoretical framework

\section{Research method}

Sample and procedure

To conduct an empirical test on the study model (refer to figure 1), Glasgow's brand personality as a tourist destination was investigated. The data of this study consisted of Chinese outbound tourists in Glasgow, including independent and group tourists. In respect of the selection of sample size, it is suggested that minimum sample size in a range of 150-400 for the analysis via structural equation model (Hair et al. 2006). Specifically, the sample size of this study consisted of 226 randomly selected Chinese tourists aged 18 and older. They were situated around Glasgow city centre. The selection of the location was due to the highest number of Chinese outbound tourists.

Data collection was conducted between March 2019 and July 2019. The items of each construct of interest were extracted from the existing scales, and the research context was adopted or adapted when necessary. Researchers conducted fieldwork via face-to-face questionnaire surveys in Glasgow. Surveys were psychically distributed at the two selected locations at varying times to ensure that the variability of the chosen population was represented. Although Chinese is the official language for Chinese tourists, the survey was conducted in English and Chinese. Therefore, the questionnaires were translated by the professional agency into the respective languages prior to their distribution. Based on the previous studies, several items 
were measured with 5 - point Likert scale ( $1=$ strongly disagree, $5=$ strongly agree), while the other items were measured with 7 - point Likert scale ( $1=$ strongly disagree, 7 =strongly agree). The respondents were accompanied by the researcher so that explanations regarding the survey questions could be provided if there were parts of the questions which they did not understand. In the end, 226 questionnaires were completed.

\section{Measure}

Operationalisation of destination brand personality

As a measure of brand personality, Aaker's (1997) big five human personality dimensions represented the most prominent operationalisation of brand personality. In the case of this research, 15 items were adopted from a study conducted by Chua, Kim, Lee and Han (2019) to measure destination's brand personality with five dimensions, such as sincerity, excitement, competence, sophistication, and ruggedness in the tourism context. In respect of the multidimensions, sincerity was measured by four items ("down to earth, honest, wholesome and cheerful"); excitement was measured by four items ("daring, spirited, imaginative and up to date"), competence was measured by three items ("reliable, intelligent, and successful"), sophistication was measured by two items ("high class and charming”), and ruggedness was measured by two items (“outdoorsy and tough"). Reliability values for five dimensions were presented in a previous study (Rutelione, Hopenienè, and Žalimienė 2018), Cronbach's alpha coefficient for all the defined factors was in the range of 0.772 and 0.913 .

The operationalisation of self-congruity

Consumers' self-congruity, including two dimensions, namely actual self-congruity and ideal self-congruity was measured by six items (e.g. "the image of Glasgow is consistent with how I actually see myself", "I am quite similar to the personality of Glasgow", "the personality of Glasgow is consistent with how I actually see myself", "the image of Glasgow consistent with how I would like to see myself", "I would like to be perceived as similar to the personality of Glasgow", "the personality of Glasgow is consistent with how I would like to see myself".). The items of this scale were extracted from several sources (Chua, Kim, Lee, and Han 2019; Usakli and Baloglu 2011). Reliability values for actual self-congruity and ideal self-congruity were illustrated in a previous study (Huang, Zhang, and Hu 2017), Cronbach's alpha coefficient for all the defined factors was 0.79 and 0.83 . 
Operationalisation of revisit intention

Revisit intention was measured by three items ("I consider Glasgow as my first choice compared to other countries to revisit", "I have a strong intention to revisit Glasgow on my next trip", and "I have a strong intention to visit Glasgow in my distant future"). The items for this scale were adapted from a previous study (Foroudi, Akarsu, Ageeva, Foroudi, Dennis, and Melewar 2018). Reliability values for revisit intention was indicated in a previous study (Foroudi, Akarsu, Ageeva, Foroudi, Dennis, and Melewar 2018), Cronbach's alpha coefficient for all the defined factors was 0.96 .

Operationalisation of gender

The moderating effects of gender on the predictive capability of tourist revisiting intention was investigated. This was followed by the mediated relationship between self-congruity and tourist revisiting intention. As a result, it was found that that $69.5 \%$ of our final sample of 226 respondents were female, leaving the remaining percentage representing the male respondents.

\section{Data analysis}

Data analyses were performed using SPSS and Partial Least Squares (PLS). Meanwhile, the descriptive analysis was employed to profile the demographic respondents via SPSS. In order to assess the measurement and structural models, the PLS approach to structural equation modelling (SEM) was applied (Ringle, Wende, and Will 2005). The smart PLS is superior to covariance-based approaches in SEM when dealing with model complexity (Chin 1998, 2010; Hair et al. 2011, 2012). The measurement and structural models encompass 24 indicators and 8 latent variables. The latent variables consist of five constructs of destination personality traits, two constructs of self-congruity and one construct of revisit intention. According to Hair et al. (2012), this number of latent variables exceeds the average number of variables and paths, especially compared to the covariance-based application in SEM. For instance, Shah and Goldstein (2006) suggested that an average of 4.7 latent variables each study when reviewing applications for covariance-based SEM. Therefore, since the model of this study is rather complex, PLS-SEM is accepted as an effective approach. In order to conduct hypothesis testing, the standard PLS algorithm was performed to assess the significance level of the estimates based on 5000 bootstraps, as suggested by Hair et al. (2011). 


\section{Results}

\section{Profile of respondents}

In this study a majority of Chinese tourists are female (69.5\%). Approximately $72 \%$ of the respondents are under 25 years of age. Hence, it could be deduced that most of the young Chinese tourists are more likely to visit Glasgow. Moreover, $93.5 \%$ of them are single. In average, $31.4 \%$ of the tourists earn between 10001-20000 RMB. In addition, $68.1 \%$ of respondents prefer independent travelling, while $63.3 \%$ of respondents are first-timers to Glasgow.

\section{Assessment of the Measurement Model}

A two-step approach was adopted for this study following the recommendations of Anderson and Gerbing (1988). The first step is to examine and evaluate the convergent validity and reliability. Convergent validity is achieved when the model satisfies the following criteria. First, loadings should exceed 0.5 (Bagozzi and Yi 1988). Since this model consists of two loadings (DP11 and DP12), values less than 0.5 are recommended to be omitted according to Hair et al. (2014). Secondly, the composite reliability should exceed 0.7 (Gefen, Straub, and Boudreau 2000). Finally, Fornell and Lacker (1981) stated that an average variance extracted (AVE) should exceed 0.5 . Hence, based on the results, the model was found to meet all of the above criteria as depicted in Table 1 and Figure 2.

Table 1: Measurement model of PLS ( $n=226)$

\begin{tabular}{|c|c|c|c|c|}
\hline Latent variable & Items & Loading & AVE & Composite Reliability \\
\hline \multirow[t]{3}{*}{ Actual self-congruity } & ASC1 & 0.840 & \multirow{3}{*}{0.742} & \multirow{3}{*}{0.896} \\
\hline & ASC2 & 0.899 & & \\
\hline & ASC3 & 0.844 & & \\
\hline \multirow[t]{4}{*}{ Sincerity } & DP1 & 0.670 & \multirow{4}{*}{0.540} & \multirow{4}{*}{0.824} \\
\hline & DP2 & 0.758 & & \\
\hline & DP3 & 0.783 & & \\
\hline & DP4 & 0.724 & & \\
\hline \multirow[t]{4}{*}{ Excitement } & DP5 & 0.619 & \multirow{4}{*}{0.530} & \multirow{4}{*}{0.817} \\
\hline & DP6 & 0.670 & & \\
\hline & DP7 & 0.813 & & \\
\hline & DP8 & 0.793 & & \\
\hline \multirow[t]{2}{*}{ Competence } & DP9 & 0.874 & \multirow{2}{*}{0.756} & \multirow{2}{*}{0.861} \\
\hline & DP10 & 0.865 & & \\
\hline
\end{tabular}




\begin{tabular}{lllll}
\hline Sophistications & DP13 & 1.000 & 1.000 & 1.000 \\
\hline Ruggedness & DP14 & 0.700 & \multirow{2}{*}{0.659} & 0.791 \\
\cline { 2 - 3 } & DP15 & 0.910 & & \\
\hline Ideal self-congruity & ISC1 & 0.818 & & 0.730 \\
\cline { 2 - 3 } & ISC2 & 0.882 & 0.890 \\
\cline { 2 - 3 } & ISC3 & 0.862 & & \\
\hline Revisit intention & RI1 & 0.873 & & 0.927 \\
\cline { 2 - 3 } & RI2 & 0.924 & \\
\cline { 2 - 3 } & RI3 & 0.898 & & \\
\hline
\end{tabular}

Note: DP11 and DP12 were excluded due to AVE of less than 0.50; AVE: Average Variance Extracted.

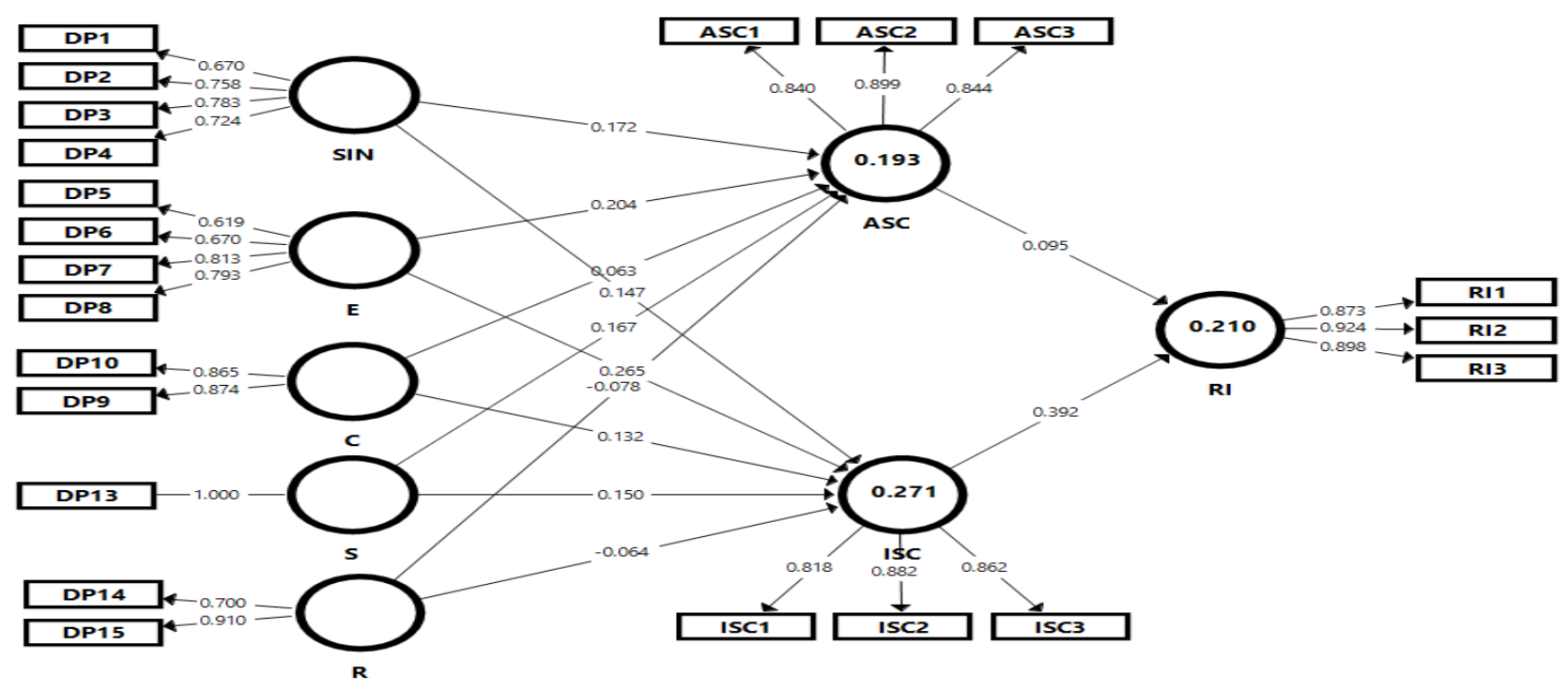

Figure 2: PLS-Path analysis of R-square values $(n=226)$

\section{Discriminant validity}

The following step examines the discriminant validity. Discriminant validity (Table 2) was tested using the HTMT criterion (Henseler, Ringle, and Sarstedt 2015), where the discriminant validity is established if the values pass the .85 threshold (Kline 2011). Based on the evaluations, the model of convergent validity, reliability and discriminant validity was qualified. 
Table 2: Discriminant validity of Heterotrait-Monotrait Ratio (HTMT) (n=226)

\begin{tabular}{llllllllr}
\hline Construct & 1 & 2 & 3 & 4 & 5 & 6 & 7 \\
\hline 1. Actual self-congruity & & & & & & & \\
2. Competence & 0.427 & & & & & & \\
3. Excitement & 0.450 & 0.880 & & & & & \\
4. Ideal self-congruity & 0.780 & 0.559 & 0.592 & & & & \\
5. Ruggedness & 0.300 & 0.618 & 0.838 & 0.366 & & & \\
6. Revisit intention & 0.401 & 0.465 & 0.485 & 0.534 & 0.388 & & \\
7. Sophistication & 0.368 & 0.594 & 0.620 & 0.427 & 0.595 & 0.401 & \\
8. Sincerity & 0.403 & 0.671 & 0.667 & 0.451 & 0.824 & 0.397 & 0.480 \\
\hline
\end{tabular}

\section{Assessment of the structural model}

\section{Direct effects}

Although only indirect effects were tested between each variable in this study based on theoretical assumptions, direct effects do need to be determined prior to running the Smart PLS analysis and analysing indirect effects. This study employed a bootstrapping technique with 5000 bootstrap samples to test the hypothesis. It applies a values for one-tailed t-test of 1.645 $($ significant level $=0.05), 2.327($ significant level $=0.01)$ and $3.092($ significant level $=0.001)$ (Hair et al. 2017). Based on the bootstrapping process, the table 3 indicated coefficient values and t-values exposed the presence of direct effects.

Table 3: Significance of direct effects- Path coefficients $(n=226)$

\begin{tabular}{lcclll}
\hline Path & Beta value & SE & t-value & p-values & Result \\
\hline $\mathrm{ASC} \rightarrow$ RI & 0.096 & 0.074 & 1.301 & 0.097 & Not Supported \\
$\mathrm{C} \rightarrow$ ASC & 0.063 & 0.082 & 0.770 & 0.221 & Not Supported \\
$\mathrm{C} \rightarrow \mathrm{ISC}$ & 0.132 & 0.087 & 1.511 & 0.065 & Not Supported \\
$\mathrm{E} \rightarrow$ ASC & 0.204 & 0.096 & $2.114^{*}$ & 0.017 & Supported \\
$\mathrm{E} \rightarrow$ ISC & 0.265 & 0.087 & $3.061^{* * *}$ & 0.001 & Supported \\
$\mathrm{ISC} \rightarrow$ RI & 0.389 & 0.076 & $5.101^{* * *}$ & 0.000 & Supported \\
$\mathrm{R} \rightarrow$ ASC & -0.078 & 0.077 & 1.019 & 0.154 & Not Supported \\
$\mathrm{R} \rightarrow$ ISC & -0.064 & 0.084 & 0.767 & 0.222 & Not Supported \\
$\mathrm{S} \rightarrow$ ASC & 0.167 & 0.086 & $1.945^{*}$ & 0.026 & Supported \\
$\mathrm{S} \rightarrow$ ISC & 0.150 & 0.084 & $1.787^{*}$ & 0.037 & Supported \\
$\mathrm{SIN} \rightarrow$ ASC & 0.172 & 0.077 & $2.227^{*}$ & 0.013 & Supported \\
$\mathrm{SIN} \rightarrow$ ISC & 0.147 & 0.078 & 1.897 & 0.029 & Supported \\
\hline
\end{tabular}

Note: ${ }^{*} \mathrm{p}<0.05, \mathrm{t}>1.645,{ }^{*} \mathrm{p}<0.01, \mathrm{t}>2.327,{ }^{* * *} \mathrm{p}<0.001, \mathrm{t}>3.092$ (one-tailed); SE: Standard Error 


\section{Indirect effects}

In order to test the hypotheses, a bootstrapping procedure with a resampling rate of 5000 (Hair et al. 2017) was performed to obtain the Beta value, t-values, p-values, and bootstrapped confidence intervals. As our previous proposed hypothesis was based on theoretical assumption, we proposed a hypothesis based on indirect relationships between the five dimensions of destination personality, self-congruity and revisit intention. Table 4 presents the results of the specific indirect effects of path coefficients. The results indicated that the self-congruity is not fully mediated between destination personality with the five different traits. However, ideal self-congruity $(\beta=0.057, \mathrm{t}$-value $=1.675, \mathrm{p}<0.05)$ was found to mediate the relationship between destination personality with sincerity and revisit intention. Moreover, ideal self-congruity $(\beta=0.103$, t-value=2.766, $\mathrm{p}<0.05)$ also mediated the relationship between destination personality with excitement and revisit intention. Therefore, H6 and H7 were supported, while H1, H2, H3, H4, H5, H8, H9 and H10 were not supported.

Table 4: Significance of specific indirect effects- Path coefficients $(n=226)$

\begin{tabular}{lccccl}
\hline Path & Beta value & SE & t-value & p-values & \multicolumn{1}{c}{ Result } \\
\hline $\mathrm{C} \rightarrow \mathrm{ASC} \rightarrow \mathrm{RI}$ & 0.006 & 0.011 & 0.550 & 0.291 & $\begin{array}{l}\text { Not } \\
\text { Supported }\end{array}$ \\
$\mathrm{E} \rightarrow \mathrm{ASC} \rightarrow \mathrm{RI}$ & 0.020 & 0.020 & 0.967 & 0.167 & $\begin{array}{l}\text { Not } \\
\text { Supported }\end{array}$ \\
$\mathrm{R} \rightarrow \mathrm{ASC} \rightarrow \mathrm{RI}$ & -0.008 & 0.010 & 0.718 & 0.236 & $\begin{array}{l}\text { Not } \\
\text { Supported }\end{array}$ \\
$\mathrm{S} \rightarrow \mathrm{ASC} \rightarrow \mathrm{RI}$ & 0.016 & 0.016 & 1.001 & 0.158 & $\begin{array}{l}\text { Not } \\
\text { Supported }\end{array}$ \\
$\mathrm{SIN} \rightarrow \mathrm{ASC} \rightarrow \mathrm{RI}$ & 0.017 & 0.016 & 1.034 & 0.151 & $\begin{array}{l}\text { Not } \\
\text { Supported }\end{array}$ \\
$\mathrm{C} \rightarrow \mathrm{ISC} \rightarrow \mathrm{RI}$ & 0.051 & 0.037 & 1.386 & 0.083 & $\begin{array}{l}\text { Not } \\
\text { Supported }\end{array}$ \\
$\mathrm{E} \rightarrow \mathrm{ISC} \rightarrow \mathrm{RI}$ & 0.103 & 0.037 & 2.766 & 0.003 & $\begin{array}{l}\text { Supported } \\
\mathrm{R} \rightarrow \mathrm{ISC} \rightarrow \mathrm{RI}\end{array}$ \\
& -0.025 & 0.033 & 0.747 & 0.227 & $\begin{array}{l}\text { Not } \\
\text { Supported }\end{array}$ \\
$\mathrm{S} \rightarrow \mathrm{ISC} \rightarrow \mathrm{RI}$ & 0.058 & 0.036 & 1.628 & 0.052 & $\begin{array}{l}\text { Not } \\
\text { Supported }\end{array}$ \\
$\mathrm{SIN} \rightarrow \mathrm{ISC} \rightarrow \mathrm{RI}$ & 0.057 & 0.034 & 1.675 & 0.047 & Supported \\
\hline
\end{tabular}

Note: ${ }^{*} \mathrm{p}<0.05, \mathrm{t}>1.645, * * \mathrm{p}<0.01, \mathrm{t}>2.327, * * * \mathrm{p}<0.001, \mathrm{t}>3.092$ (one tailed); SE: Standard Error 
To test moderator effect of gender, two interaction terms were found insignificant. Based on Table 5, support was exhibited between actual self-congruity*gender $\rightarrow$ revisit intention $(\beta=0.072, \mathrm{t}$-value $=0.641, \mathrm{p}<0.05)$ and self-congruity*gender $\rightarrow$ revisit intention $(\beta=0.063, \mathrm{t}$ value $=0.646, \mathrm{p}<0.05$ ). Thus, $\mathrm{H} 11$ and $\mathrm{H} 12$ were not supported. Hence, it does not matter if actual and ideal self-congruity is high or low.

Table 5: Significance of direct effects- Path coefficients $(n=226)$

\begin{tabular}{lccccl}
\hline Path & Beta value & SE & t-value & p-values & Result \\
\hline ASC $*$ Gender $\rightarrow$ RI & 0.072 & 0.112 & 0.641 & 0.261 & Not Supported \\
ISC $*$ Gender $\rightarrow$ RI & 0.063 & 0.097 & 0.646 & 0.259 & Not Supported \\
\hline
\end{tabular}

Note: ${ }^{*} \mathrm{p}<0.05, \mathrm{t}>1.645,{ }^{*} \mathrm{p}<0.01, \mathrm{t}>2.327,{ }^{*} * \mathrm{p}<0.001, \mathrm{t}>3.092$ (one tailed); SE: Standard Error

\section{R-square value and Q-square}

The size of the R-square was used as a criterion for predictive relevance, a predictive sample reuse procedure (also known as the Stone-Geisser's (1974) $Q^{2}$ can also be applied). Henseler et al. (2009) also stated that this measure can be used to assess the research model's capability to predict. Based on the blindfolding procedure, $\mathrm{Q}^{2}$ evaluates the predictive validity of a model via PLS. $Q^{2}$ values larger than zero indicate exogenous constructs possess predictive relevance for the endogenous construct (Hair et al. 2011). In this study, table 6 indicated that the $Q^{2}$ of actual self-congruity $\left(Q^{2}=0.122>0\right)$, ideal self-congruity $\left(Q^{2}=0.179>0\right)$ and of revisit intention $\left(Q^{2}=0.158>0\right)$ demonstrated that the research model has excellent predictive relevance (Table 8).

Table 6: R-Square value and Q-Square value $(n=226)$

\begin{tabular}{lcc}
\hline Endogenous Variable & R-Square & Q-Square \\
\hline Actual self-congruity & 0.193 & 0.122 \\
\hline Ideal self-congruity & 0.271 & 0.179 \\
\hline Revisit intention & 0.210 & 0.158 \\
\hline
\end{tabular}

\section{Discussion and conclusion}

The objective of this study was to examine the self-congruity as a mediating effect between the multi-dimensions of destination brand personality and revisit intention among Chinese tourists in Glasgow. The city of Glasgow in the UK is a popular tourist destination, hence, was selected as the site for data collection. First and foremost, H6 is empirically supported in the present study. Our findings indicated that ideal self-congruity mediates the relationship between destination brand personality with sincerity and revisit intention. Current findings are also 
consistent with studies conducted by Usakli and Baloglu (2011), where both studies agreed that the influence of sincerity on revisit intention thought the self-congruity. Secondly, H7 is also empirically supported in this study. The current findings indicated that ideal self-congruity mediates the relationship between destination brand personality with excitement and revisit intention. In line with previous literature on the context of Chinese tourism destination, our findings varied moderately. To the contrary, Huang, Zhang and $\mathrm{Hu}$ (2017) reported that there was no mediating effect of ideal self-congruity between excitement and destination branding. Hence, based on the findings, it was suggested that the motivation for Chinese outbound tourists to revisit Glasgow is on the basis of congruency between destination brand personality with sincerity, excitement and their ideal self-concept. Similarly, Chinese outbound tourists tend to prefer destination brand personality is consist of how they would like to see themselves such as sincerity and excitement. Ideal self-congruity, however, did not mediate the relationship between destination brand personality with competence, sophistication and ruggedness and revisit intention in this study. More importantly, our findings also demonstrated that the mediating effect of actual self-congruity has no significance at all between the five dimensions (i.e. sincerity, excitement, competence, sophistication and ruggedness) of destination brand personality and revisit intention.

The destination brand personality, self-congruity and revisit intention are much-discussed constructs and are utilised in an empirical test construct in tourism marketing (Sirgy et al. 1997; Helgeson and Supphellen 2004; Uşakl and Baloglu 2011). Other constructs, however, have not been considered. Most studies documented the significant effects of demographic gender in marketing and tourism literature (Dube and Morgan 1996; Garbarino and Strahilevitz 2004; Dedeoğlu, Balıkçıoğlu, and Küçükergin 2016; Akinci and Aksoy 2019). This study examined the moderating effects of gender on the relationship between self-congruity and revisit intention. Current findings indicated that the demographic variable (i.e. gender) has no effect between actual and ideal self-congruity also revisit intention. Therefore, the demographic variable of gender does not play a significant role in predicting Chinese outbound tourists' intention to revisit Glasgow. Additionally, there are still several interesting results which can be clarified in this study. Prior to the addition of a moderator variable of interaction, the $\mathrm{R}^{2}$ value of the dependent variable was $21 \%$. Once the variable of moderator interaction was added, the $\mathrm{R}^{2}$ value of the dependent variable was estimated at $22.1 \%$. There is an increase by $1.1 \%$ in term of $\mathrm{R}^{2}$ value. Hence, the introduction of the moderator of gender in this study is 
important. A significant moderator of gender is possible if the sample size of this study was larger.

\section{Implications}

This study generated both theoretical and managerial implications. From the theoretical standpoint, the findings of this study contributed to the understanding of a theoretical model by explaining the interrelationships between the multidimensional destination brand personality, self-congruity and revisit intention. Based on previous literature, the effects of destination brand personality on the self-congruity(Huang, Zhang, and $\mathrm{Hu} 2017$ ), selfcongruity and revisit intention (Rutelione, Hopenienè, and Žalimienè 2018), and both destination brand personality and self-congruity on revisit intention (Chua, Kim, Lee, and Han 2019; Uşakl and Baloglu 2011; Liu, Lin, and Wang 2012) have been emphasised. However, little has been done in the literature to examine the interrelationship between multidimensional destination brand personality, self-congruity and revisit intention in a tourism setting of Glasgow city. This deficiency is serious because it is generally accepted that multidimensional destination brand personality is a powerful means for enhancing differentiation and that differentiation is a significant competitive marketing strategy (Liu, Lin, and Wang 2012; Kim, Malek, Kim, and Kim 2017). Accordingly, this study built up its theoretical model to hypothesize the mediating role of self-congruity in relation to multidimensional destination brand personality and Chinese tourists' revisit intention to Glasgow. Considering a processoriented view, we hypothesized that self-congruity would mediate the effects of two dimensions (i.e sincerity and excitement) of destination brand personality on revisit intention. Therefore, this study has contributed to the literature by improving the understanding of the mediating role of self-congruity in the relationship between multi-destinations of destination brand personality and revisit intention.

Furthermore, the other theoretical contribution of this study is to provide a better understanding of the theory of self-congruity in the tourism marketing literature. The current findings also explain self-congruity theory (the greater the match between destination brand personality and tourists' self-concept, the more likely is that tourists will have a favourable attitude toward that destination, leading to intention to revisit) but our findings do not fully support self-congruity theory in tourism destination (e.g. Glasgow city). This study evidenced ideal self-congruity as a mediator between destination brand personality with a dimension of sincerity and excitement. In other words, sincerity and excitement have an indirect effect on revisit intention through ideal self-congruity. 
Next, this study contributes to the tourism marketing literature by exploring the moderating impact of gender on self-congruity and revisit intention. However, the nonsignificant moderating effect of gender on the relationship between self-congruity and revisit intention is an indication that the inclusion of gender as the latent construct does not contribute or strengthen the impact of self-congruity on the revisit intention among Chinese outbound tourists in Glasgow. The literature so far has indicated that there is no study that has examined the moderating effect of gender on self-congruity and revisit intention. Hence, results of the moderating effect of this study are a unique contribution of this study.

Regarding managerial implications, the current results triggered several implications for DMOs, especially for destination marketers. Nowadays, DMOs face an increase in tough competition than before. Hence, marketing communication alone that attributes to holiday destinations no longer help attract tourists due to the high product similarity and growing sustainable development. Current results also provided evidence that city destination brand personality with multi-dimensions is important in understanding the complex nature of tourists' behaviour. As expected, the results indicated ideal self-congruity as a mediator effect between destination brand personality with sincerity, excitement and revisit intention. However, the current results also revealed that only two dimensions, sincerity and excitement, were able to predict tourists' revisit intention to Glasgow through the ideal self-congruity. Chinese tourists who interconnect how they perceive destinations brand personality and how they would like to see their personality are more likely to have a favourable attitude towards Glasgow, thus, leading to their intention to revisit. Therefore, destination marketers in Glasgow should place great emphasis on establishing the association between Glasgow brand personality and Chinese tourist's self-concept and implication several marketing strategies (segmentation, position and promotional mixed) emphasis this match. The combination of destination brand personality and self-congruity could provide a more comprehensive understanding of how Chinese tourists choose their destination.

Our result also demonstrated that the moderating role of gender in relation to destination brand personality and self-congruity has no significance. Based on this result, it could be argued that there is no difference between the destination brand personality of males and females over selfcongruity while considering the impact of symbolic destination brand benefits on their 
intention to revisit. These findings would also help destination marketers in Glasgow to apply marketing segmentation and target tourists' demographic profile (biological sex).

\section{Limitation and further studies}

The present study has several limitations. First, the most significant limitation of this study is the sample size. Data collection took place between March 2019 and July 2019, as the main researcher was a $\mathrm{PhD}$ visiting scholar in the UK. So we were not able to reach out to larger sample size. Hence, a future study replicating this study could use a larger sample size, as this might improve the interaction of gender as a moderator. Next, this study adapted two dimensions of self-congruity namely actual self-congruity and ideal self-congruity only. The other two dimensions of social self-congruity and ideal social self-congruity were yet included in this study. It is worth mentioning that social self-congruity has given rise to increased attention in tourism discipline. Tourist behaviour towards destination choice is not only influenced by personal factors but also by social factors. Hence, we encourage researchers to examine the impact of social self-congruity on tourism destination.

Thirdly, the limitation of this study is also the lack of focusing on the alternative purposes of Chinese tourists intention to revisit Glasgow. Hence, we encourage researchers to also explore the special interests tourism (SIT) such as revisit intention on art tourism, spa tourism and gambling tourism through our theoretical framework. Additionally, a further research agenda could also investigate the role of other moderating variables such as trip related factors (e.g. travel purpose, travel companions) or cultural related factors (e.g. uncertainty avoidance ) or demographics (e.g. age, nationality, level of income, level of education) in this relationship. Finally, we would like to argue that according to the background of tourists who perceive a high level of self-congruity, the effects of destination brand personality on revisit intention could differ. Therefore, future studies could examine the moderation role of self-congruity in linking destination brand personality and revisit intention.

\section{Ethical approval}

This project has been approved by College of Social Sciences at University of Glasgow's Ethics Committee (Reference number: 400180196). If you have any ethics queries, you can contact to Dr. Muir Houston, College of Social Sciences Ethics Officer, University of Glasgow 
(E-mail: Muir.Houston@glasgow.ac.uk) who will be pleased to discuss any concerns you may have about participation in this project.

\section{Acknowledgement}

We would like to extend our gratitude to Erasmus and University of Glasgow for the approval of research grant, hence enabling us to do fieldwork and achieve the project. This research was funded by University of Glasgow as part of the Erasmus + ICM programme 2017-1-UK01KA107-036056, Sponsor Licence Number: TRAW6PAA8. We are also grateful to the editor and blind reviewers of the Journal of International Consumer Marketing for their valuable comments and feedback. 


\section{References}

Aaker, J. L. 1997. Dimensions of brand personality. Journal of Marketing Research 34(3): 347-356.

Aaker, J. L., V. Benet-Martínez, and J. Garolera. 2001. Consumption symbols as carriers of culture: a study of Japanese and Spanish brand personality constructs. Journal of Personality and Social Psychology 81(3): 492-508. doi:10.1037/0022-3514.81.3.492

Aguirre-Rodriguez, A., M. Bosnjak, and M. J. Sirgy. 2012. Moderators of the self-congruity effect on consumer decision-making: A meta-analysis. Journal of Business Research 65 : 1179-1188. doi: 10.1016/j.jbusres.2011.07.031

Abubakar, A. M., M. Ilkan, R. M. Al-Tal, and K. K. Eluwole. 2017. eWOM, revisit intention, destination trust and gender. Journal of Hospitality and Tourism Management 31: 220-227. doi:10.1016/j.jhtm.2016.12.005

Akinci, S., and S. Aksoy. 2019. The impact of service recovery evaluation on word-of-mouth intention: A moderated mediation model of overall satisfaction, household income and gender. Tourism Management Perspectives 31: 184-194. doi: 10.1016/j.tmp.2019.05.002

Allison, N. K., L. L. Golden, G. M. Mullet, and D. Coogan. 1980. Sex-typed product images: the effects of sex, sex role self-concept and measurement implications. Advances in Consumer Research 7 (1): 604-609.

Anderson, J. C., and D. W. Gerbing. 1988. Structural equation modelling in practice: A review and recommended two-step approach. Psychological Bulletin 103(3): 411-423.

Apostolopoulou, A., and D. Papadimitriou. 2015. The role of destination personality in predicting tourist behaviour: implications for branding mid-sized urban destinations. Current Issues in Tourism 18(12):1132-1151. doi: 10.1080/13683500.2013.878319

Birdwell, A. E. 1968. A study of the influence of image congruence on consumer choice. Journal of Business 41(1): 76-88. doi: stable/2351957

Bagozzi, R. P., and T. Yi. 1988. On the evaluation of structural equation models. Journal of Academy of Marketing Science 16(1): 74-94. doi: org/10.1007/BF02723327

Bakewell, C., and V. W. Mitchell. 2006. Male versus female consumer decision making styles. Journal of business research 59(12):1297-1300. doi:10.1016/j.jbusres.2006.09.00

Bakewell, C., and V. W. Mitchell. 2003. Generation Y female consumer decision-making styles. International Journal of Retail and Distribution Management 31 (2): 95-106. doi: 10.1108/09590550310461994 
Bakewell, C., and V. W. Mitchell. 2004. Male consumer decision-making styles. International Review of Retail, Distribution and Consumer Research 14 (2): 223-240. doi: 10.1080/0959396042000178205

Beerli, A., G. D. Meneses, and S. M. Gil. 2007. Self-congruity and destination choice. Annals of Tourism Research 34(3): 571-58. doi:10.1016/j.annals.2007.01.005

Boksberger, P., S. Dolnicar, C. Laesser, and M. Randle. 2011. Self-congruity theory: to what extent does it hold in tourism? Journal of Travel Research 50(4): 454-464. doi: 10.1177/0047287510368164

Claiborne, C. B., and M. J. Sirgy. 1990. Self-congruity as a model of attitude formation and change: Conceptual review and guide for future research. In B. J. Dunlap (Ed.), Developments in marketing science (Vol. 13, pp. 1-17). Cullowhee, NC: Academy of Marketing Science.

Chang, C. 2006. The influence of masculinity and femininity in different advertising processing contexts: An accessibility perspective. Sex Roles 55(5-6): 345-356. doi: 10.1007/s11199-006-9088-x

Chen, C. F., and S. Phou. 2013. A closer look at destination: Image, personality, relationship and loyalty. Tourism Management 36: 269-278.doi: org/10.1016/j.tourman.2012.11.015

Chin, W. 1998. The partial least squares approach for structural equation modeling. In G. A. Marcoulides (Ed.), Methodology for business and management 295-336 Mahwah, NJ: Lawrence Erlbaum Associates Inc.

Chin, W. W. 2010. How to write up and report PLS analyses. In V. Esposito Vinzi, W. W. Chin, J. Henseler, and H. Wang (Eds.), Handbook of partial least squares 655-690. Berlin Heidelberg: Springer.

Chon, K. 1992. Self-image/destination image congruity. Annals of Tourism Research 19(2): 360-363. doi: doi.org/10.1016/0160-7383(92)90090-C

Chua, B. L., H. C. Kim, S. Lee, and H. Han. 2019. The role of brand personality, self-congruity, and sensory experience in elucidating sky lounge users' behaviour. Journal of Travel \& Tourism Marketing 36(1): 29-42. doi: 10.1080/10548408.2018.1488650

Collins, D., and C. Tisdell. 2002. Gender and difference in travel life cycles. Journal of Travel Research 41: 133-134. doi: 10.1177/004728702237413

d'Astous, A., and L. Boujbel. 2007. Positioning countries on personality dimensions: Scale development and implications for country marketing. Journal of Business Research, 60(3): 231-239. doi: 10.1016/j.jbusres.2006.11.005

d'Astous, A., and M. Levesque. 2003. A scale for measuring store personality. Psychology \& Marketing 20(5): 455-469. doi: 10.1002/mar.10081

Darley, W.K., and R. E. Smith. 1995. Gender differences in information processing strategies: an empirical test of the selectivity model in advertising response. Journal of Advertising 24 (1): 4156.

Das, G. 2014. Impacts of retail brand personality and self-congruity on store loyalty: the moderating role of gender. Journal of Retailing and Consumer services 21(2): 130-138. doi: 10.1016/j.jretconser.2013.07.011 
De Moya, M., and R. Jain. 2013. When tourists are your "friends": Exploring the brand personality of Mexico and Brazil on Facebook. Public Relations Review 39(1): 23-29. doi: 10.1016/j.pubrev.2012.09.004

Dedeoğlu, B. B., S. Balıkçığlu and K. G. Küçükergin. 2016. The role of tourist's value perceptions in behavioural intentions: The moderating effect of gender. Journal of Travel \& Tourism Marketing 33(4): 513-534. doi: 10.1080/10548408.2015.1064062

Dholakia, R.R. 1999. Going shopping: key determinants of shopping behaviors and motivations. International Journal of Retail and Distribution Management 27 (4): 154-166. doi: $10.1108 / 09590559910268499$

Dolich, J. 1969. Congruence relationships between self-images and product brands. Journal of Marketing Research 8 (1): 80-84.

Dubé, L., and M. S. Morgan. 1996. Trend effects and gender differences in retrospective judgments of consumption emotions. Journal of consumer research 23(2): 156-162. doi: 10.1086/209474

Edinburgh News. 2016. Tourist who preferred Glasgow to Edinburgh is inundated with offers to revisit $\begin{array}{lllll}\text { the } & \text { Cap. } & \text { Accessed } & \end{array}$ https://www.edinburghnews.scotsman.com/news/people/tourist-who-preferred-glasgowedinburgh-inundated-offers-revisit-capital-614099

Eisend, M., and N. E. Stokburger-Sauer. 2013a. Brand personality: a meta- analytic review of antecedents and consequences. Marketing Letters 24(3): 205-216.

Eisend, M., and N. E. Stokburger-Sauer. 2013b. Measurement characteristics of Aaker's brand personality dimensions: lessons to be learned from human personality research. Psychology \& Marketing 30(11): 950-958. doi: 10.1002/mar.20658

Ekinci, Y., and S. Hosany. 2006. Destination personality: An application of brand personality to tourism destinations. Journal of travel research 45(2):127-139. doi: 10.1016/j.tourman.2010.06.006

Ekinci, Y., and M. Riley. 2003. An investigation of self-concept: actual and ideal self- congruence compared in the context of service evaluation. Journal of Retailing and Consumer Services 10(4): 201-214. doi: 10.1016/S0969-6989(02)00008-5

Ekinci, Y., E. Sirakaya-Turk, and S. Baloglu. 2007. Host image and destination personality. Tourism Analysis 12(5-6): 433-446.

Fornell, C., and D. F. Lacker. 1981. Evaluation structural equation models with unobserved variables and measurement error. Journal of Marketing Research 18(1): 39-50.

Foroudi, P., T. N. Akarsu, E. Ageeva, M. M. Foroudi, C. Dennis, and T. C. Melewar. 2018. Promising the dream: Changing destination image of London through the effect of website place. Journal of Business Research 83: 97-110. doi: 10.1016/j.jbusres.2017.10.003

Funk, D. C., K. Toohey, and T. Bruun. 2007. International sport event participation: Prior sport involvement; destination image; and travel motives. European Sport Management Quarterly 7(3): 227-248. doi: 10.1080/16184740701511011

Graeff, T. R. 1996. Using promotional messages to manage the effects of brand and self-image on brand evaluations. Journal of Consumer Marketing 13(3): 4-18. doi:10.1108/ 07363769610118921 
Grubb, E. L., and B. L. Stern. 1971. Self-concept and significant others. Journal of Marketing Research 8(3): 382-385. doi: 10.1177/002224377100800319

Grubb, E. L., and H. L. Grathwohl. 1967. Consumer self-concept, symbolism and market behaviour: A theoretical approach. The Journal of Marketing 31: 22-27. doi:10.1177/002224296703100405

Garbarino, E., and M. Strahilevitz. 2004. Gender differences in the perceived risk of buying online and the effects of receiving a site recommendation. Journal of Business Research 57(7): 768-775. doi: 10.1016/S0148-2963(02)00363-6

Gefen, D., D. W. Straub, and M. C. Boudreau. 2000. Structural equation modelling and regression: Guidelines for research practice. Communications of the Association for Information Systems 4:179. doi: 10.17705/1CAIS.00407

Geuens, M., B. Weijters, and K. De Wulf. 2009. A new measure of brand personality. International Journal of Research in Marketing 26(2): 97-107. doi: 10.1016/j.ijresmar.2008.12.002

Gould, S. J., and C. E. Weil. 1991. Gift-giving roles and gender self-concepts. Sex Roles 24(9-10): 617637.

Grohmann, B. 2009. Gender dimensions of brand personality. Journal of marketing research 46(1):105119. doi: $10.1509 / \mathrm{jmkr} .46 .1 .105$

Hair Jr, J. F., M, Sarstedt, L. G. Hopkins, and V. Kuppelwieser. 2014. Partial least squares structural equation modeling (PLS-SEM) An emerging tool in business research. European Business Review 26(2): 106-121. doi: 10.1108/EBR-10-2013-0128

Hair, J. F., W.C. Black, B. J. Babin, R. E. Anderson, and R. L. Tatham. 2006. Multivariate data analysis (6th ed.). NJ: Prentice Hall.

Hair, J. F., G. T. M. Hult, C. M. Ringle, and M. Sarstedt. 2017. A primer on partial least squares structural equation modeling (PLS-SEM) (2nd ed). Thousand Oaks, CA: Sage.

Hair, J. F., C, M. Ringle, and M. Sarstedt. 2011. PLS-SEM: indeed a silver bullet. The Journal of Marketing Theory and Practice 19(2):139-152. doi: 10.2753/MTP1069-6679190202

Hair, J. F., M. Sarstedt, C. Ringle, and J. Mena. 2012. An assessment of the use of partial least squares structural equation modelling in marketing research. Journal of the Academy of Marketing Science 40(3): 414-433. doi: 10.1007/s11747-011-0261-6

Han, H., L.T. Hsu, and J. S. Lee. 2009. Empirical investigation of the roles of attitudes toward green behaviours, overall image, gender and age in hotel customers' eco-friendly decision-making process. International Journal of Hospitality Management 28(4): 519-528. doi: 10.1016/j.ijhm.2009.02.004

Helgeson, J. G., and M. Supphellen. 2004. A conceptual and measurement comparison of self-congruity and brand personality: The impact of socially desirable responding. International Journal of Market Research 46(2): 205-233. doi: 10.1177/147078530404600201

Henseler, J. \& G. Fassott. 2009. Testing moderating effects in PLS path models: An illustration of available procedures. In: V. Esposito Vinzi, W.W. Chin, J. Henseler \& H. Wang (Eds), Handbook of partial least squares: Concept methods and applications. Berlin: Springer. 
Henseler, J., C. M. Ringle and M. Sarstedt. 2016. Testing Measurement Invariance of Composites Using Partial Least Squares. International Marketing Review 33(3): 405-431. doi: 10.1108/IMR-092014-0304

Hosany, S., Y. Ekinci, and M. Uysal. 2006. Destination image and destination personality: an application of branding theories to tourism places. Journal of Business Research 59(5): 638-642. doi: 10.1016/j.jbusres.2006.01.001

Huang, Z., C. Zhang, and J. Hu. 2017. Destination brand personality and destination brand attachmentthe involvement of self-congruence. Journal of Travel \& Tourism Marketing 34(9): 1198-1210. doi:10.1080/10548408.2017.1330171

Hayakawa, S. I. 1963. Symbol, status, and personality (Vol. 110). Mariner Books.

Hughes, G. D., and J. L. Guerrero. 1971. Automobile self-congruity models reexamined. Journal of Marketing Research 8(1):125-127. doi:10.1177/002224377100800123

Johar, J. S., and M. J. Sirgy. 1991. Value-expressive versus utilitarian advertising appeals: When and why to use which appeal. Journal of Advertising 20: 23-33. doi: 10.1080/00913367.1991.10673345

Kahle, L. R., and P. Homer. 1985. Androgyny and midday mastication: do real men eat quiche? Advances in Consumer Research 12 (1): 242-246.

Khazaei Pool, J., M. Khodadadi, and A. Asadi. 2018. The impact of congruence between self-concept and destination personality on behavioural intentions for visiting an Islamic-historical destination. Tourism and Hospitality Research 18(3): 378-387. doi: 10.1177/1467358416663820

KILICcedil, B., and S. A. Sop. 2012. Destination personality, self-congruity and loyalty. Journal of Hospitality Management and Tourism 3(5): 95-105. doi: 10.5897/JHMT12.024

Kim, K., and G. Jogaratham. 2003. Activity preferences of Asian international and domestic American students: An alternate basis for segmentation. Journal of Vacation Marketing 9: 260-274. doi $10.1177 / 135676670300900305$

Kim, S., and X. Y. Lehto. 2013. Projected and perceived destination brand personalities: The case of South Korea. Journal of Travel Research 52(1): 117-130. doi: 10.1177/0047287512457259

Kim, W., K. Malek, N. Kim, and S. Kim. 2017. Destination personality, destination image, and intent to recommend: The role of gender, age, cultural background, and prior experiences. Sustainability 10(1): 87. doi: 10.3390/su10010087

Kline, R. B. 2011. Principles and practice of structural equation modelling. New York NY: Guilford Press.

Kolyesnikova, N., T. H. Dodd, and J. B. Wilcox. 2009. Gender as a moderator of reciprocal consumer behaviour. Journal of Consumer Marketing 26(3): 200-213. doi: 10.1108/07363760910954136

Landon, E. L., Jr. 1974. Self-concept, ideal self-concept, and consumer purchase intentions. Journal of Consumer Research 1(2): 44-51.

Laroche, M., G. Saad, M. Cleveland, and E. Browne. 2000. Gender differences in information search strategies for a Christmas gift. Journal of Consumer Marketing 17 (6): 500-522. doi: $10.1108 / 07363760010349920$ 
Lam, S. K., M. Ahearne, and N. Schillewaert. 2012. A multinational examination of the symbolicinstrumental framework of consumer-brand identification. Journal of International Business Studies 43(3): 306-331. doi: 10.1057/jibs.2011.54

Litvin, S. W., and G. H. Kar. 2004. Individualism/collectivism as a moderating factor to the self-image congruity concept. Journal of Vacation Marketing 10(1): 23-32. doi: $10.1177 / 135676670301000103$

Lee, Y. K., K. J. Back, and J. Y. Kim. 2009. Family restaurant brand personality and its impact on customer's emotion, satisfaction, and brand loyalty. Journal of hospitality \& tourism research 33(3): 305-328. doi: 10.1177/1096348009338511

Li, H., C. Kuo, and M. G. Rusell. 1999. The impact of perceived channel utilities, shopping orientations, and demographics on the consumer's online buying behaviour. Journal of Computer-Mediated Communication 5(2): 521. doi 10.1111/j.1083-6101.1999.tb00336.x

Liu, C. R., W. R. Lin, and Y. C. Wang. 2012. From destination image to destination loyalty: Evidence from recreation farms in Taiwan: 从目的地意象到目的地忠诚之模式探讨：以台湾休闲农场 为例. Journal of China Tourism Research 8(4): 431-449. doi: 10.1080/19388160.2012.729427

Liu, Z., S. S. Huang, R. Hallak, and M. Liang. 2016. Chinese consumers' brand personality perceptions of tourism real estate firms. Tourism Management 52:310-326. doi: 10.1016/j.tourman.2015.06.022

Malhotra, N. K. 1988. Self-concept and product choice: an integrated perspective. Journal of Economic Psychology 9(1):1-28 doi: 10.1016/0167-4870(88)90029-3

Matzler, K., A. Strobl, N. Stokburger-Sauer, A. Bobovnicky, and F. Bauer. 2016. Brand personality and culture: The role of cultural differences on the impact of brand personality perceptions on tourists' visit intentions. Tourism Management 52: 507-520. doi 10.1016/j.tourman.2015.07.017

Mitchell, V.-W., and G. Walsh. 2004. Gender differences in German consumer decision- making styles. Journal of Consumer Behaviour 3 (4): 331-346. doi: 10.1002/cb.146

Murphy, L., P. Benckendorff, and G. Moscardo. 2007. Linking travel motivation, tourist self-image and destination brand personality. Journal of Travel \& Tourism Marketing 22(2): 45-59. doi: 10.1300/J073v22n02_04

Onkvisit, S., and J. Shaw. 1987. Self-concept and image congruence: some research and managerial implications. Journal of Consumer Marketing 4(1): 13-23. doi:10.1108/eb008185

Palan, K.M. 2001. Gender identity in consumer behaviour research: a literature review and research agenda. Academy of Marketing Science Review 10: 1-31.

Papadimitriou, D., A. Apostolopoulou, and K. Kaplanidou. 2015. Destination personality, affective image, and behavioural intentions in domestic urban tourism. Journal of Travel Research 54(3): 302-315. doi: $10.1177 / 0047287513516389$

Pan, L., M. Zhang, D. Gursoy, and L. Lu. 2017. Development and validation of a destination personality scale for mainland Chinese travellers. Tourism Management 59: 338-348. doi: 10.1016/j.tourman.2016.08.005

Ringle, C. M., S. Wende, and A. Will. 2005. SmartPLS 2.0 (beta). Hamburg: Germany. 
Rutelione, A., R. Hopenienè, and K. Žalimienè. 2018. Linking Destination Brand Personality, Selfcongruity and Tourist Behaviour: A Local Spa resort case study. Lex Localis-Journal of Local Self-Government16(2). doi.org/10.4335/16.2.293-310

Shah, R., and S. M. Goldstein. 2006. Use of structural equation modeling in operations management research: looking back and forward. Journal of Operations Management 24(2):148-169. doi:10.1016/j.jom.2005.05.001

Siguaw, J. A., A. Mattila, and J. R. Austin. 1999. The brand-personality scale: An application for restaurants. Cornell Hotel and Restaurant Administration Quarterly 40(3): 48-55. doi: $10.1177 / 001088049904000319$

Sirgy, M. J. 1982. Self-concept in consumer behavior: a critical review. Journal of Consumer Research 9(3): 287-300.

Sirgy, M. J., and C. Su. 2000. Destination image, self-congruity, and travel behavior: toward an integrative model. Journal of Travel Research 38(4): 340-352. doi: 10.1177/004728750003800402

Sirgy, M.J. 1982. Self-concept in consumer behaviour: a critical review. Journal of Consumer Research 9 (3): 287-300. doi:10.1086/208924

Sirgy, M. J. 1985a. Self-image/product-image congruity and consumer decision making. International $\begin{array}{lllll}\text { Journal of } & \text { Management } & \text { 49-63. }\end{array}$

Sirgy, M. J. 1985b. Using self-congruity and ideal congruity to predict purchase motivation. Journal of Business Research 13: 195-206.

Sirgy, M. J., D. Grewal, T. F. Mangleburg, J. O. Park, K. S. Chon, C. B. Claiborne, and H. Berkman. 1997. Assessing the predictive validity of two methods of measuring self-image congruence. Journal of the Academy of Marketing Science 25: 229-241. doi: 10.1177/0092070397253004

Sirgy, M. J., D. J. Lee, and G. B. Yu. 2017. Revisiting self-congruity theory in consumer behavior: Making sense of the research so far. In C. Jansson-Boyd \& M. Zawisza (Eds.), Routledge international handbook of consumer psychology (pp. 185-201). London: Routledge, Taylor \& Francis.

Sirgy, M. J., J. S. Johar, A. C. Samli, and C. B. Claiborne. 1991. Self-congruity versus functional congruity: Predictors of consumer behavior. Journal of the Academy of Marketing Science 19: 363-375. doi: doi.org/10.1007/BF02726512

Stokburger-Sauer, N. E., S. Ratneshwar, and S. Sen. 2012. Drivers of consume rebrand identification. International Journal of Research in Marketing 29(4): 406-418. doi: 10.1016/j.ijresmar.2012.06.001

Stone, M. 1974. Cross-validatory choice and assessment of statistical predictions. Journal of the royal statistical society. Series B (Methodological), 111-147.

$\mathrm{Su}$, N., and D. Reynolds. 2017. Effects of brand personality dimensions on consumers' perceived selfimage congruity and functional congruity with hotel brands. International Journal of Hospitality Management 66: 1-12. doi: 10.1016/j.ijhm.2017.06.006

Terry, M. 2019. Daily business. Scotland's so good we want to come back, say Chinese tourists. Accessed December 25, 2019 https://dailybusinessgroup.co.uk/2019/10/scotlands-so-good-we-want-tocome-back-say-chinese-tourists/

Todd, S. 2001. Self-concept: A tourism application. Journal of Consumer Behaviour 1(2): 184-196. doi:10.1002/(ISSN)1479-1838 
Usakli, A., and S. Baloglu. 2011. Brand personality of tourist destinations: an application of self-congruity theory. Tourism Management 32(1):114-127. doi: 10.1016/j.tourman.2010.06.006

Worth, L.T., J. Smith, and D. M. Mackie. 1992. Gender schematicity and preference for gender-typed products. Psychology \& Marketing 9 (1): 17-30. doi: 10.1002/mar.4220090104

Wang, X. 2019. The Guardian. How the Chinese fell in love with the Highlands. Accessed December 25, 2019. https://www.theguardian.com/travel/shortcuts/2019/jan/23/how-the-chinese-fell-in-lovewith-the-highlands

Xie, K. L., and J. S. Lee. 2013. Toward the perspective of cognitive destination image and destination personality: the case of Beijing. Journal of Travel and Tourism Marketing 30(6): 538-556. doi: /doi.org/10.1080/10548408.2013.810993

Yang, S., S. M. Isa, and T. Ramayah. 2019. The understanding of Chinese outbound tourists' behaviour toward revisit New Zealand: A Conceptual Development. In Proceedings of the Cambridge Conference Series 27- 28. Cambridge, April, 8th-10th, 2019.

Yang, S., S. M. Isa, T. Ramayah, and R. Blanes. 2019. The development of a conceptual framework on the brand personality, self-congruity and tourist loyalty: the moderator role of tourist emotional experience. In 9th advances in hospitality and tourism marketing and management conference proceedings 532. 